\title{
Uma análise do Depoimento Especial e da Escuta Especializada como mecanismos de preservação de crianças e adolescentes vítimas de violência sexual
}

\author{
An analysis of the Special Testimony and Specialized Listening as mechanisms for the preservation \\ of children and adolescents victims of sexual violence
}

Un análisis del Testimonio Especial y la Escucha Especializada como mecanismos para la preservación de niños, niñas y adolescentes víctimas de violencia sexual

\author{
Ana Carla Seibel Maciel \\ ORCID: https://orcid.org/0000-0002-4067-5833 \\ Universidade de Cruz Alta, Brasil \\ E-mail: anacarlaseibelmaciel84@gmail.com \\ Angela Simone Pires Keitel \\ ORCID: https://orcid.org/0000-0002-0516-0623 \\ Universidade de Cruz Alta, Brasil \\ E-mail: angelakeitel@unicruz.edu.br \\ Vanessa Steigleder Neubauer \\ ORCID: https://orcid.org/0000-0001-6182-3455 \\ Universidade de Cruz Alta, Brasil \\ E-mail: vneubauer@unicruz.edu.br \\ Deivid Jonas Silva da Veiga \\ ORCID: https://orcid.org/0000-0002-1625-0560 \\ Escola Superior do Ministério Público, Brasil \\ E-mail: deividveiga96@gmail.com \\ Aline Antunes Gomes \\ ORCID: https://orcid.org/0000-0003-4845-5664 \\ Universidade de Cruz Alta, Brasil \\ E-mail: algomes@unicruz.edu.br \\ Ieda Márcia Donati Linck \\ ORCID: https://orcid.org/0000-0001-5984-4003 \\ Universidade de Cruz Alta, Brasil \\ E-mail: imdlinck@gmail.com
}

\begin{abstract}
Resumo
O presente artigo teve como objetivo analisar as implicações da Lei 13.431 de 2017 que estabelece algumas garantias de direitos da criança e do adolescente, vítima ou testemunha de violência e altera o Estatuto da Criança e do Adolescente, Lei $\mathrm{n}^{\circ} 8.069$, de 13 de julho de 1990. O problema de pesquisa exposto consiste em analisar a técnica do depoimento pessoal, método alternativo de inquirição de vítimas de abuso sexual, cumprindo a função para a qual foi criado, ou seja, evitar a revitimização de crianças e adolescentes vítimas de abuso sexual intrafamiliar. Para atingir os propósitos do estudo, inicialmente, na primeira seção, foi feita uma abordagem geral dos direitos das crianças e dos adolescentes e as principais legislações para sua proteção. Em seguida, na segunda seção trata de uma abordagem sobre os tipos de violência e na última seção faz uma pesquisa acerca do estudo específico da escuta especializada e do depoimento especial, trazendo as principais mudanças da legislação nesse sentido e analisando os possíveis benefícios desses instrumentos para as vítimas de abuso sexual. A metodologia se baseia em uma abordagem qualitativa bibliográfica, tendo como método de pesquisa o hipotético-dedutivo e como método de abordagem o histórico-comparativo. Como resultado desta pesquisa foi possível verificar que a criação dos novos mecanismos de oitiva tem por objetivo central proteger os infantojuvenil se evitar uma possível revitimização através da aplicação da escuta especializada e do depoimento especial.
\end{abstract}

Palavras-chave: Abuso sexual; Infanto-juvenil; Depoimento especial.

\section{Abstract}

This article aimed to analyze the implications of Law 13,431 of 2017, which establishes certain guarantees for the rights of children and adolescents, victims or witnesses of violence and amends the Statute of Children and Adolescents, Law 8,069, of July 13, 1990. The research problem exposed consists of analyzing the technique of personal testimony, an alternative method of interrogating victims of sexual abuse, fulfilling the function for which it was created, that is, avoiding the re-victimization of children and adolescents victims of intrafamily sexual abuse. . To 
achieve the purposes of the study, initially, in the first section, a general approach was made on the rights of children and adolescents and the main legislation for their protection. Then, in the second section it deals with an approach on the types of violence and in the last section it does a research about the specific study of specialized listening and the special testimony, bringing the main changes of the legislation in this sense and analyzing the possible benefits of these instruments for victims of sexual abuse. The methodology is based on a qualitative bibliographic approach, using the hypothetical-deductive as the research method and the historical-comparative as the method of approach. As a result of this research, it was possible to verify that the creation of new hearing mechanisms has the central objective of protecting children and adolescents if they avoid a possible revictimization through the application of specialized listening and special testimony.

Keywords: Sexual abuse; Child's-juveniles; Special testimony.

\section{Resumen}

Este artículo tuvo como objetivo analizar las implicaciones de la Ley 13.431 de 2017, que establece ciertas garantías para los derechos de las niñas, niños y adolescentes víctimas o testigos de violencia y reforma el Estatuto de la Niñez y la Adolescencia, Ley 8.069, de 13 de julio de 1990. El problema de investigación expuesto consiste en analizar la técnica del testimonio personal, método alternativo de interrogatorio de víctimas de abuso sexual, cumpliendo la función para la que fue creado, es decir, evitar la revictimización de niños, niñas y adolescentes víctimas de abuso sexual intrafamiliar. . Para lograr los propósitos del estudio, inicialmente, en el primer apartado se realizó un abordaje general sobre los derechos de la niñez y la adolescencia y las principales legislaciones para su protección. Luego, en el segundo apartado se aborda un abordaje sobre los tipos de violencia y en el último apartado se hace una investigación sobre el estudio específico de la escucha especializada y el testimonio especial, trayendo los principales cambios de la legislación en este sentido y analizando la posibles beneficios de estos instrumentos para las víctimas de abuso sexual. La metodología se basa en un enfoque bibliográfico cualitativo, utilizando el hipotético-deductivo como método de investigación y el histórico-comparativo como método de abordaje. Como resultado de esta investigación, se pudo constatar que la creación de los nuevos mecanismos de audición tiene como objetivo central proteger a los niños, niñas y adolescentes si evitan una posible revictimización mediante la aplicación de la escucha especializada y el testimonio especial.

Palabras clave: Abuso sexual; Infanto juvenil; Testimonio especial.

\section{Introdução}

A violência contra a criança ou adolescente se mostra como um fenômeno jurídico, social e cultural deveras preocupante. Neste sentido o Estatuto da Criança e do Adolescente (ECA) se apresenta como um significativo instrumento para que a sociedade e o estado possam, reconhecendo o protagonismo desses sujeitos, buscar superar as formas de violência que prejudicam o seu crescimento e o desenvolvimento físico, moral e psíquico (Minayo, 2001).

Neste mesmo cenário, a violência sexual é um problema grave e muito presente na sociedade ainda mais quando se trata de crianças e adolescentes. Contudo, cabe destacar que a violência sexual é gênero tendo como espécies o abuso e a exploração sexual. Neste sentido, ressalta-se que o presente artigo irá abordar apenas os casos de abuso sexual, com ênfase no abuso sexual intrafamiliar.

Inicialmente, destaca-se que a promulgação da Lei $\mathrm{n}^{\circ}$ 13.431, em 04 de abril de 2017, constitui-se um dos mais recentes mecanismos destinados a coibir a violência contra crianças e adolescentes, cujas modificações surgiram com a finalidade de melhorar a legislação nesta área, instituindo, basicamente, duas formas igualmente válidas para coletar prova junto a crianças e adolescentes vítimas ou testemunhas de violência no âmbito do inquérito policial ou processo judicial, quais sejam, a escuta especializada e o depoimento especial, a serem realizados por profissionais qualificados, em local adequado, respeitando o tempo, desejos e opiniões da criança e/ou adolescente (RO em Habeas Corpus n ${ }^{\circ}$. 117.204-SP, STJ, rel. Ministro Reynaldo Soares da Fonseca, J. 28.2.2020).

Além da alteração nos procedimentos, a norma também trouxe um novo olhar para o atendimento, como crianças e adolescentes vítimas ou testemunhas de violência são vistas, entendidas e atendidas por parte do Poder Público, ou seja, busca um olhar mais humanizado (Digiácomo, \& Digiácomo, 2018).

Dessa forma a presente pesquisa delimita-se na abordagem do depoimento especial e escuta especializada, como método que visa atender as peculiaridades atinentes a crianças e adolescentes vítimas de abuso sexual. 
O objetivo geral da pesquisa é analisar as implicações da Lei $\mathrm{n}^{\circ}$ 13.431/17, que estabelece algumas garantias de direitos da criança e do adolescente, vítima ou testemunha de violência, bem como analisar os métodos alternativos de inquirição através do depoimento especial e da escuta especializada, verificando a efetividade do depoimento especial como forma de evitar a revitimização das crianças e adolescentes vítimas de abuso sexual. Para tanto, abordar-se-á ao longo deste artigo, as definições e eficácia dos métodos acerca da escuta especializada e do depoimento especial, observando os requisitos e preparação dos profissionais para a inquirição das vítimas.

Perante esse contexto, a pesquisa possui a seguinte problemática: A técnica do depoimento especial e escuta especializada, como método alternativo de inquirição de vítimas de abuso sexual cumpre de modo eficaz a função a qual foi criado, ou seja, evitar a revitimização dos infanto-juvenis?

Nesse sentido, a resposta para a indagação desta pesquisa é de que crianças e adolescentes possuem especial proteção na legislação brasileira, sendo contempladas por uma série de direitos, das quais a família, a sociedade e o Estado possuem o dever de garantir. Dessa forma, através da implementação, mediante lei, do depoimento especial, método alternativo de inquirição, crianças e ou adolescentes, vítimas de abuso sexual, passaram a contar com o referido procedimento, pressupondo assim, que estão resguardados das sucessivas inquirições sobre o mesmo fato que os vitimou, evitando sua revitimização.

Com relação à estrutura da pesquisa, inicialmente será apresentado na primeira seção uma breve evolução histórica da defesa dos direitos da criança e do adolescente, após abordar-se-á questão da violência contra as crianças, entrando nas garantias previstas pela lei do depoimento especial.

\section{Metodologia}

A presente pesquisa obteve seu desenvolvimento a partir do método qualitativo bibliográfico. Reconhece-se que as pesquisas realizadas sob o aspecto qualitativo se valem de métodos de interpretação subjetivos com destaque ao entendimento de vertentes que cercam a construção histórica da sociedade como crenças, valores, ações e individualidades com seus efeitos no meio social (Minayo, 1983).

Deste modo foi desenvolvida uma pesquisa com base em artigos, doutrinas, reportagens, revistas jurídicas e científicas e em ambiente virtual, da área pertinente, buscando também analisar o estudo das violações dos direitos das crianças e adolescentes, em especial através da prática do abuso sexual, cuja violação afronta os direitos fundamentais garantidos pelo ECA, bem como constitucionalmente, apontar como ocorre o processo de implementação dos métodos alternativos de inquirição através da escuta especializada e do depoimento especial, visto que a concretização dessas garantias é primazia de todo Estado Democrático de Direito. Salienta-se que as pesquisas bibliográficas são tão relevantes quanto qualquer outro tipo de pesquisa, uma vez que concede uma renovação da informação, sendo pertinente para qualquer área do conhecimento (Severino, 2018).

O método de pesquisa abordado é o hipotético-dedutivo, que conforme Popper (1975), é uma metodologia que busca solucionar questionamentos mediante a formulação de hipóteses ou teorias, já com intuito de eliminar possíveis empecilhos a surgir no curso da pesquisa.

Quanto ao método de procedimento adotado têm-se o método histórico-comparativo, que de acordo com Durkheim (1987, [s.p]) trata-se "[...] de um modo de demonstrar que entre dois fatos existe uma relação lógica, uma relação de causalidade [...]", consistindo desta forma em uma criação de ligações causais, onde a demonstração que um fenômeno é causado por outro ocorre mediante o exame de casos, onde ambos estão presentes, podendo-se verificar se realmente um encontra ligado ao outro. 


\section{Resultados e Discussão}

\subsection{Sintetizando a evolução histórica da defesa dos direitos da criança e adolescente}

Nem sempre as crianças e adolescentes foram considerados sujeitos de direitos, apresentando registros de uma história marcada por desconsideração, na sociedade e no próprio campo normativo, tanto que as leis protetivas, tanto no âmbito internacional quanto nacional, são bastante recentes.

No longínquo ano de 1896, ocorreu um dos primeiros grandes marcos históricos para o Direito da Criança, conhecido como "Caso Marie Anne", e considerado como um exemplo histórico da luta dos direitos da criança e adolescente. Segundo Saraiva (2005, p. 33):

A menina de nove anos sofria intensos maus-tratos impostos pelos pais, fato que chegou ao conhecimento público de Nova Iorque daquela época. O certo é que os pais julgavam-se donos dos filhos e que poderiam educá-los como lhes aprouvesse. O castigo físico- até hoje utilizado por alguns- era visto como método educativo e sendo as criançascomo animais- propriedade de seus donos, no caso dos pais, poderiam ser educadas da forma que entendessem. O fato é que a situação degradante, de tão notória que ficou, chegou aos Tribunais. Daí é que se encontra o ponto crucial e chocante: a entidade que ingressou em juízo para pleitear os direitos de Marie Anne e elidi-la dos seus agressores foi a Sociedade Protetora dos Animais de Nova Iorque. A ironia do caso é que não existia uma sociedade que protegesse a criança, mas já havia uma entidade protetora de animais. Com o fito de defender os direitos da criança, a fim de demonstrar legitimidade para agir, a Sociedade alegou que se Marie Anne fosse um cavalo, um cachorro ou um gato não deveria ser submetida a tratamento tão brutal, imagine sendo uma pessoa.

A ação foi vencida pela entidade, tendo início uma nova era no direito das crianças. Após este caso, e de outros que acabaram vindo a público, em 1899 foi criado, no Estado Americano de Illinois, o primeiro Tribunal de Menores do Mundo (Barros, 2014). Outros países seguiram o modelo americano, sendo, a Inglaterra em 1905, Alemanha em 1908, Portugal e Hungria em 1911, França em 1912, Argentina em 1921, Japão em 1922, Brasil em 1923, Espanha em 1924, México em 1927 e Chile em 1928 (Dantas, 2009).

No ano de 1919, em virtude da Primeira Guerra Mundial e a Revolução Russa, a necessidade de ajuda e proteção aos órfãos da guerra era iminente, sendo assim, surge na Inglaterra a Associação Internacional Salve as Crianças, por iniciativa de Eglantyne Jebb (Jensen, 2018). Em 1920, a associação passou a ser considerada pioneira na luta dos direitos das crianças, atuando também na elaboração da Declaração de Genebra, ou Carta da Liga. No ano de 1924 a Liga das Nações adotou a Declaração de Genebra sobre os Direitos da Criança, que trazia em seu texto que todas as pessoas devem garantir as crianças meios para seu desenvolvimento; ajuda especial em momentos de necessidade; prioridade no socorro e assistência; liberdade econômica e proteção contra exploração; e uma educação que instile consciência e dever social (Unicef, [21 --?]b). Contudo, essa declaração não atingiu o impacto necessário ao pleno reconhecimento internacional dos direitos da criança (Souza, 2002).

No Brasil a Lei no 4.242, de 5 de janeiro de 1921, assegurou a exclusão de qualquer processo penal de menores que não tivessem completado quatorze anos de idade (Dantas, 200]). "Passou-se a adotar, portanto, um critério objetivo de punibilidade, qual seja, a idade" (Dantas, 200]).

O Decreto no 17.943-4/1927, chamado de Código Mello Mattos em homenagem a seu autor, o jurista José Cândido de Albuquerque Mello Mattos ${ }^{1}$ (Pinheiro, 2014), foi a primeira lei do Brasil que se dedicou à proteção da infância e da adolescência, sendo esta legislação que estabeleceu que o jovem é penalmente inimputável até os 17 anos e que somente a partir dos 18 responde por seus crimes e pode ser condenado à prisão, no lugar da reclusão passam a serem aplicadas, as atualmente chamadas medidas socioeducativas (Westin, 2015). Ainda, conforme Westin (2015):

A nova lei, em resumo, determinava ao governo, à sociedade e à família que cuidassem bem dos menores de 18 anos.

\footnotetext{
1 Jurista que alcançou grande notoriedade no meio político e intelectual de sua época, sobre a questão da infância "abandonada" e "delinquente", durante o período em que atuou como Juiz de Menores do Distrito Federal (19241933).
} 
A partir de 1927, as crianças de até 11 anos não puderam mais trabalhar. A atividade dos adolescentes entre 12 e 17 anos ficou autorizada, porém com uma série de restrições.

De acordo com Marcílio (1998 apud Venâncio, 1999, [online]), o Código de Menores "foi revolucionário por pela primeira vez obrigar o Estado a cuidar dos abandonados e reabilitar os delinquentes", ressalvando que "como sempre acontece no Brasil, há uma distância muito grande entre a lei e a prática".

Visando atender as necessidades emergenciais das crianças durante o período pós-guerra, a Organização das Nações Unidas (ONU) criou em dezembro de 1946 o Fundo das Nações Unidas para a Infância - atual UNICEF. Buscando atender projetos de longo prazo, crianças e mulheres de países em desenvolvimento, tornando-se permanente das Nações Unidas em 1953. Está presente no Brasil desde 1950, apoiando importantes transformações na área da infância e adolescência, movimentos buscando o acesso universal à educação, programas de enfrentamento ao trabalho infantil, e participou de mobilizações que resultaram na aprovação do art. 227 da Constituição (Unicef, [21--?]b).

Em 1948 foi aprovado pela Assembleia Geral das Nações Unidas a Declaração Universal dos Direitos Humanos, trazendo em seu texto ${ }^{2}$ que a "infância têm direito a cuidados e assistência especiais", e que "crianças nascidas dentro ou fora do matrimonio gozarão da mesma proteção social" (Dudh, 1948 apud Souza, 2002). Foi acatada como um grande avanço nos Direitos Humanos, reconhecendo a dignidade da pessoa humana, o direito a vida, à liberdade, a justiça social e a paz mundial. Assim, a Declaração Universal dos Direitos Humanos é considerada a maior prova histórica da importância de garantir Direitos Humanos, por meio de um determinado sistema de valores (Bobbio, 2009 apud Delfino, 2009, p. 10).

Segundo a Unicef ([21--?]a, [online]):

Direitos humanos são tudo o que um ser humano deve ter ou ser capaz de fazer para sobreviver, prosperar e alcançar todo o seu potencial. Todos os direitos são igualmente importantes e estão conectados entre si. A Declaração Universal dos Direitos Humanos reconhece os direitos humanos como um pré-requisito para a paz, a justiça e a democracia. O caracter universal dos direitos humanos significa que valem igualmente para todos, crianças e adolescentes. Eles, não obstante, tem alguns direitos humanos adicionais que responde as suas necessidades especificas em termos de proteção e de desenvolvimento. Todas as crianças e todos os adolescentes tem os mesmos direitos. Esses direitos também estão conectados, e todos são igualmente importantes - eles não podem ser tirados das crianças e adolescentes.

A Declaração dos Direitos da Criança, formada por dez princípios que asseguram em síntese, o direito da criança à proteção especial; à ser-lhe dadas as oportunidades e facilidades necessárias ao pleno desenvolvimento saudável e harmonioso; à utilizar-se dos benefícios relativos à seguridade social, incluindo-se a adequada nutrição, moradia, recreação e serviços médicos; à receber educação e a ser protegida contra todas as formas de negligência, crueldade e exploração, foi adotada pela Assembleia Geral das Nações Unidas no ano de 1959 (Unicef, [21--?]a). Conforme Dantas (2009, [online]):

A Declaração dos Direitos da Criança, se constitui, como afirmado, em um mecanismo fundamental para conquistas relevantes nos direitos da criança. A legislação internacional começa a se livrar das amarras da cultura tutelar (total irresponsabilidade juvenil) para dar os primeiros passos para atingir a Doutrina da Proteção Integral. Tenta-se retirar o menor da condição de objeto da norma e transformá-lo em sujeito da norma, titular de direitos e obrigações.

No ano de 1979, é promulgado no Brasil um novo Código de Menores, a Lei nº 6.697/1979, que entrou em vigor nos últimos anos da ditadura militar, o referido código_adotou a "denominada doutrina da situação irregular, que dispunha sobre a assistência, proteção e vigilância a menores de até dezoito anos de idade, que se encontrassem em situação irregular” (Zapater, 2018, [online]), ou seja, a criança é objeto da norma somente quando se encontrar em estado de abandono social. Segundo

\footnotetext{
${ }^{2}$ Artigo XXV 1. Todo ser humano tem direito a um padrão de vida capaz de assegurar-lhe, e a sua família, saúde e bem-estar, inclusive alimentação, vestuário, habitação, cuidados médicos e os serviços sociais indispensáveis, e direito à segurança em caso de desemprego, doença, invalidez, viuvez, velhice ou outros casos de perda dos meios de subsistência em circunstâncias fora de seu controle. 2. A maternidade e a infância têm direito a cuidados e assistência especiais. Todas as crianças, nascidas dentro ou fora do matrimônio gozarão da mesma proteção social.
} 
Saraiva (2005, p. 53):

No período de vigência do Código de Menores, cerca de $80 \%$ dos menores que ocupavam o sistema FEBEM não cometeram infrações penais definidos em nossa legislação. Estavam lá não por serem autores de infrações, mas por serem vítimas do descaso. Existia, na verdade, uma espécie de controle da pobreza. Cerceavam a liberdade dos menores sem respeitar garantias mínimas processuais.

Logo a doutrina da Proteção Integral ganhou forças com a Constituição Federal de 1988. No Brasil, a Constituição Federal de 1988 foi um marco histórico para os direitos do cidadão brasileiro. Conhecida também como "Constituição Cidadã", trouxe aos indivíduos residentes no país, uma gama de direitos, concentrados principalmente em seu art. $5^{\circ}$.

O caput do referido art., já revela os principais direitos assegurados ao homem, determinando que "todos são iguais perante a lei, sem distinção de qualquer natureza, garantindo-se aos brasileiros e aos estrangeiros residentes no país a inviolabilidade do direito à vida, à liberdade, à igualdade, à segurança e à propriedade". Desta forma, não há como esquecer, também das garantias das crianças e adolescente expressas na Constituição Federal, e do dever dos pais em garantir boas condições de vida e sobrevivência aos filhos. O supramencionado diploma constitucional, refere-se exclusivamente, no art. $227^{3}$, o dever dos pais em relação aos descendentes. Em relação a crianças e adolescentes, a Constituição Federal contempla, por meio de diretivas compatíveis com a normativa internacional, "assentando que a condição peculiar de seus integrantes redundava necessariamente na urgência de um atendimento prioritário e sob o viés determinado pela doutrina da proteção integral" (Santos, 2015, p. 113).

O constituinte reconheceu a vulnerabilidade da criança e do adolescente, agindo com o objetivo de lhes "garantir igualdade material e acesso pleno à cidadania, instituindo, inclusive, em seu favor uma série de direitos fundamentais especiais", estruturados a partir de suas específicas necessidades (Santos, 2015, p. 114).

A Convenção sobre os Direitos da Criança foi adotada pela Assembleia Geral da ONU em novembro de 1989, considerada o instrumento de direitos humanos mais aceito na história universal, reconhecendo os papeis das crianças como atores sociais, econômicos, políticos, civis e culturais, garantindo e estabelecendo padrões mínimos para proteger os direitos das crianças (Unicef, [21--?]a). Essa Convenção, é um importante documento para definir as obrigações aos Estados, especialmente em relação a legislação interna dos países signatários, além de criação de políticas públicas e de instituições capazes de garantir os direitos da criança e dos adolescentes. Outrossim, podem ser citados outros documentos internacionais, como a Convenção relativa às Piores Formas de Trabalho Infantil (1999); a Convenção Relativa à Adoção Internacional (1995) e dois Protocolos Facultativos à Convenção dos Direitos da Criança, um relativo à Participação de Crianças em Conflitos Armados (2000) e outro sobre Tráfico de Crianças e Prostituição Infantil (2004), todas buscando a tutela dos direitos da criança e do adolescente (Jerez et al., 2013).

Em 13 de julho de 1990 o Brasil aprovou o Estatuto da Criança e do Adolescente (ECA), tonando-se um marco legal da defesa de direitos das crianças e adolescentes, fundando-se na ideia de que estes também são sujeitos de direito, merecendo acesso a cidadania e proteção. A proteção integral da criança e do adolescente expressa nesta lei, regula o art. 227 da Constituição Federal de 1988, fazendo da família, do Estado e de toda a sociedade, os responsáveis por garantir a proteção dos titulares da lei. Desta forma, segundo Tavares (2002, p. 9):

Declara o primeiro art. do Estatuto quem são os sujeitos desse direito especial: a criança e o adolescente. E o objeto: a proteção integral desses titulares. Conduta devida pelo Estado, pela família, pelas entidades comunitárias, pela sociedade em geral e por cada cidadão em particular. Regulando assim o preceito do art. 227 da Constituição Federal.

\footnotetext{
${ }^{3}$ Art. 227. É dever da família, da sociedade e do Estado assegurar à criança, ao adolescente e ao jovem, com absoluta prioridade, o direito à vida, à saúde, à alimentação, à educação, ao lazer, à profissionalização, à cultura, à dignidade, ao respeito, à liberdade e à convivência familiar e comunitária, além de colocá-los a salvo de toda forma de negligência, discriminação, exploração, violência, crueldade e opressão.
} 
Vieira, Pini e Abreu (2015) lecionam que o Estatuto da Criança e do Adolescente concretiza o paradigma da doutrina da proteção integral que expressa notável avanço democrático, ao regulamentar as conquistas relativas aos direitos das crianças e adolescentes.

Salienta-se que tanto a Convenção Internacional dos Direitos da Criança, em âmbito internacional, quanto a Constituição Federal de 1988 e o ECA, atribuem ao Estado e à sociedade em geral, o dever de reconhecerem a condição peculiar de desenvolvimento das criança e dos adolescentes, assegurando todas as condições para a plena formação destes sujeitos. Ainda sobre o surgimento do ECA, Gadotti discorre (2015, p. 15):

O ECA foi fruto de intensas articulações e resultado de muita luta da sociedade civil no contexto da redemocratização e da conquista de novos direitos no Brasil. Muitas foram as discussões que precederam a criação do ECA, sobretudo a partir de 1985, com a criação do Movimento Nacional de Meninos e Meninas de Rua, e, depois, com a promulgação da Constituição Federal de 1988, cujo art. 227 atribui à família, à sociedade e ao Estado a responsabilidade de se constituírem como um sistema responsável pela efetivação dos direitos das crianças e dos adolescentes. Com a nova Constituição estava superada a doutrina do Código de Menores que considerava crianças e adolescentes vivendo em "situação irregular" como "objetos" de intervenção dos adultos e do Estado, já que não eram considerados "sujeitos de direitos".

Ademais, reforçando os direitos fundamentais expressos constitucionalmente, os quais são inerentes à pessoa humana, o art. $3^{04}$ do ECA também assegura à criança e ao adolescente a proteção integral. Importante destacar que, apesar de não possuírem a maioridade, ou não possuírem todas as obrigações que um adulto possui, não podem ser considerados diferentes ou menosprezados por serem crianças e adolescentes. Justamente por este motivo, devem ter proteção integral, considerando suas peculiaridades de pessoa humana, ainda em fase de desenvolvimento (Mendes, 2006).

Como direitos fundamentais básicos da criança e adolescente, o art. $7^{\text {o5 }}$ do Estatuto da Criança e do Adolescente (Brasil, 1990), garante o direito à vida e a saúde, reforçando ainda mais o art. 227 da Constituição Federal, garantindo sua proteção antes mesmo do nascimento, tendo em vista que o ECA também dispõe sobre as garantias da gestante e nascituro ${ }^{6}$.

Portanto, mais do que um dever da família e do Estado, a proteção integral da criança e do adolescente passa a ser de todo cidadão. Qualquer ação ou omissão, seja dos pais, Estado ou sociedade, que cause prejuízo à integridade dos titulares do Estatuto, estará contrariando o que garante a lei e a norma constitucional, sujeito às penas dispostas no Título VII do ECA (Brasil, 1990).

Lembrando ainda que, independente de idade, crianças e adolescentes também possuem outros direitos, o art. $15^{7}$ do ECA (Brasil, 1990), assegura outras garantias, como o direito à liberdade, respeito e à dignidade, reforçando os diretos fundamentais assegurados no art. $5^{\circ}$ da Constituição Federal (Brasil, 1988), a "repetição" destas garantias só reforça a necessidade de proteção por parte das crianças para que possam alcançar o pleno desenvolvimento.

Neste sentido, com o intuito de fortalecer os direitos da criança e do adolescente, mais instrumentos foram criados, os

\footnotetext{
${ }^{4}$ Art. $3^{\circ} \mathrm{A}$ criança e o adolescente gozam de todos os direitos fundamentais inerentes à pessoa humana, sem prejuízo da proteção integral de que trata esta Lei, assegurando-se lhes, por lei ou por outros meios, todas as oportunidades e facilidades, a fim de lhes facultar o desenvolvimento físico, mental, moral, espiritual e social, em condições de liberdade e de dignidade. (Brasil, 1990)

${ }^{5}$ Art. $7^{\circ} \mathrm{A}$ criança e o adolescente têm direito a proteção à vida e à saúde, mediante a efetivação de políticas sociais públicas que permitam o nascimento e o desenvolvimento sadio e harmonioso, em condições dignas de existência. (Brasil, 1990)

${ }^{6}$ Art. $8^{\circ}$ : É assegurado à gestante, através do Sistema Único de Saúde, o atendimento pré e perinatal.

$\S 1^{\circ}$ : A gestante será encaminhada aos diferentes níveis de atendimento, segundo critérios médicos específicos, obedecendo-se aos princípios de regionalização e hierarquização do Sistema.

$\S 2^{\circ}$ : A parturiente será atendida preferencialmente pelo mesmo médico que a acompanhou na fase pré-natal.

$\S 3^{\circ}$ : Incumbe ao poder público propiciar apoio alimentar à gestante e à nutriz que dele necessitem.

$\S 4^{\circ}$ : Incumbe ao poder público proporcionar assistência psicológica à gestante e à mãe, no período pré e pós-natal, inclusive como forma de prevenir ou minorar as consequências do estado puerperal.

$\S 5^{\circ}$ : A assistência referida no $\S 4 \mathrm{o}$ deste artigo deverá ser também prestada a gestantes ou mães que manifestem interesse em entregar seus filhos para adoção. (Brasil, 1990)

7 Art. 15. A criança e o adolescente têm direito à liberdade, ao respeito e à dignidade como pessoas humanas em processo de desenvolvimento e como sujeitos de direitos civis, humanos e sociais garantidos na Constituição e nas leis. (Brasil, 1990)
} 
quais serão tratados na próxima seção.

\subsection{Violência sexual contra crianças e adolescentes}

As crianças e adolescentes somente passaram a ser considerados sujeitos de direitos a partir da entrada em vigor do Estatuto da Criança e do Adolescente. Ao longo dos anos, o conceito de infância variou consideravelmente, consequentemente, as medidas tomadas em relação a este grupo populacional também assumiram muitas facetas. Já o conceito de adolescência surgiu apenas no século XX, denominado como o "século da adolescência" (Ariès, 1981 apud Carreirão, 2002).

Conforme Silva (2009, p. 27), "o tratamento que thes era dispensado oscilava entre considerá-los como pequenos adultos que tudo podiam fazer ou, ao revés, utilizar da pouca idade para legitimar um discurso menorista, que solapava direitos e degradava a dignidade".

Entre esses extremos, as peculiaridades dessa fase do desenvolvimento humano não eram compreendidas ou consideradas. Silva (2009, p. 28) complementa esse entendimento:

A tentativa de superação desse estado de coisas se apresenta apenas no final do último século, consolidando um esforço normativo pontuado por alguns poucos avanços e vários retrocessos em matéria legislativa. Dessa forma, ao mesmo tempo em que se encerra um período histórico marcado por avanços tecnológicos de um lado, e muita belicosidade, de outro, inaugura-se a Doutrina da Proteção Integral que, na tentativa de resgatar uma dívida histórica para com as crianças e adolescentes, reconhece sua situação peculiar de sujeitos em desenvolvimento.

Sendo assim, o centro da proteção passa da sociedade para a população infantojuvenil, considerada como merecedora de cuidados e atenção de todos os agentes sociais. O ECA surge como um marco da defesa dos direitos das crianças, "reconhecendo a vulnerabilidade e a necessidade de uma forma específica de proteção" (Masella, 2014, p. 36), oferecendo importante instrumento para que estes agentes sociais possam "buscar superar as formas de violência que prejudicam o seu crescimento e desenvolvimento e, portanto, o desenvolvimento social" (Minayo, 2001, [online]).

As crianças e os adolescentes sofrem, cotidianamente, diversos tipos de violência perpetradas nos diferentes espaços, ou seja, desde o familiar até o institucional, e as consequências desse ato acompanham as vítimas por uma vida inteira.

De acordo com a Organização Mundial da Saúde (OMS, 2018, [online]), a violência é definida como: "[...] o uso intencional da força física ou poder contra si próprio, contra outra pessoa ou contra um grupo ou comunidade que resulte ou tenha possibilidade de resultar em lesão, morte, dano psicológico, deficiência de desenvolvimento ou privação".

Além da tipologia da violência, a OMS (2018) também define distinções sobre a natureza da violência, sendo elas violência física, psicológica, tortura, violência sexual, tráfico de seres humanos, violência financeira, negligência, trabalho infantil e violência por intervenção legal. Entre as distinções mencionadas, a violência sexual, lastimavelmente, corresponde a uma das mais comuns praticadas contra criança e adolescente, sendo defino pela OMS (2018, [online]), como:

Todo ato sexual, tentativa de consumar um ato sexual ou insinuações sexuais indesejadas; ou ações para comercializar ou usar de qualquer outro modo a sexualidade de uma pessoa por meio da coerção por outra pessoa, independentemente da relação desta com a vítima, em qualquer âmbito, incluindo o lar e o local de trabalho.

Neste sentido Facuri et al. (2013, [online]) discorre sobre a violência sexual, afirmando que a referida é:

[...] um fenômeno universal, no qual não há restrição de sexo, idade, etnia ou classe social, que ocorreu no passado e ainda ocorre, em diferentes contextos ao longo da história da humanidade. Embora atinja homens e mulheres, estas são as principais vítimas, em qualquer período de suas vidas, no entanto, as mulheres jovens e adolescentes apresentam risco mais elevado de sofrer esse tipo de agressão. [...] A violência sexual tem efeitos devastadores nas esferas física e mental, em curto e longo prazos. 
Conforme discorrido por Facuri et al., resta evidente a gravidade e a presença da referida violência no meio da sociedade, atingindo jovens de ambos os sexos e todas as idades, sem deixar de ressaltar os abalos psicológicos que se perpetuam pelo decorrer da vida das vítimas.

De acordo com o Código Penal Brasileiro (Brasil, 1940), existem variados tipos de violência sexual previstos na referida norma, sendo eles: estupro ${ }^{8}$, violação sexual mediante fraude $^{9}$, importunação sexual ${ }^{10}$, assédio sexual ${ }^{11}$, estupro de vulnerável $^{12}$, corrupção de menores ${ }^{13}$, satisfação de lascívia mediante presença de criança ou adolescente ${ }^{14}$, favorecimento da prostituição ou de outra forma de exploração sexual de criança ou adolescente ou de vulnerável ${ }^{15}$.

Além do mais, é importante ressaltar que existem diferenciações entre Violência, Abuso e Exploração Sexual, que se dividem ainda em espécies, segundo Silva (2018, p. 11):

Além da definição dos maus tratos, cumpre diferenciar Violência, Abuso e Exploração Sexual. O abuso e a exploração sexual são espécies de violência sexual. Esta se subdivide em quatro tipos: prostituição, tráfico, turismo sexual e pornografia. Possui, portanto, um viés de exploração comercial. Já o abuso sexual é uma violação à dignidade sexual, podendo ser intra ou extra familiar. Muitas vezes o abuso é praticado por adultos próximos à vítima, tal como vizinhos, amigos e até membros da própria família, sendo o abuso sexual intrafamiliar uma das formas mais perversas de violência, uma vez que, conforme os ensinamentos de Luciane Potter, viola os direitos fundamentais das crianças e adolescentes, atingindo profundamente as vítimas e deixando muitas vezes mais do que apenas marcas físicas.

Desta forma, a violência sexual consiste na forma coercitiva de praticar ou tentar atos sexuais ou atos invasivos e obscenos indesejados pela outra pessoa, além dos abusos físicos existem também os abusos psicológicos e emocionais. Além disto, quando trata-se de menor de 14 anos, segundo o Código Penal brasileiro, não há forma legal de consentimento como aludem Gomes, Donatti e Fernandes (2009, [online]).

O abuso sexual não ocorre somente por meio de contato físico ${ }^{16}$, mas também de outras formas sem que envolvam o toque, sendo eles (Childhood Brasil, 2018):

a) $\quad \mathrm{O}$ assédio sexual que pode ser expresso em forma verbal, não verbal ou física, é todo o comportamento indesejado de caráter sexual.

b) $\quad \mathrm{O}$ abuso sexual verbal que pode ser definido por conversas abertas sobre atividades sexuais - falas erotizadas - destinadas a despertar o interesse da criança ou do adolescente ou a chocá-los.

c) O exibicionismo que consiste no ato de mostrar os órgãos genitais ou se masturbar em frente a crianças ou adolescentes ou dentro do campo de visão deles, e o voyeurismo que pode ser explicado como o ato de observar fixamente atos sexuais ou órgãos genitais de outras pessoas quando elas não desejam ser vistas, obtendo satisfação sexual com essa prática.

d) A exibição de material pornográfico, é quando o agressor exibe materiais pornográficos a meninas e meninos e os obriga a assistir, é uma forma de abuso sexual sem contato físico.

Assim, fica claro que os abusos sexuais não se consumam apenas mediante a violência física, como as carícias ou

\footnotetext{
${ }^{8}$ Art. 213. Constranger alguém, mediante violência ou grave ameaça, a ter conjunção carnal ou a praticar ou permitir que com ele se pratique outro ato libidinoso; (Brasil, 1940)

${ }^{9}$ Art. 215. Ter conjunção carnal ou praticar outro ato libidinoso com alguém, mediante fraude ou outro meio que impeça ou dificulte a livre manifestação de vontade da vítima; (Brasil, 1940)

${ }^{10}$ Art. 215-A. Praticar contra alguém e sem a sua anuência ato libidinoso com o objetivo de satisfazer a própria lascívia ou a de terceiro; (Brasil, 1940)

${ }^{11}$ Art. 216-A. Constranger alguém com o intuito de obter vantagem ou favorecimento sexual, prevalecendo-se o agente da sua condição de superior hierárquico ou ascendência inerentes ao exercício de emprego, cargo ou função; (Brasil, 1940)

12 Art. 217-A. Ter conjunção carnal ou praticar outro ato libidinoso com menor de 14 (catorze) anos; (Brasil, 1940)

${ }^{13}$ Art. 218. Induzir alguém menor de 14 (catorze) anos a satisfazer a lascívia de outrem; (Brasil, 1940)

14 Art. 218-A. Praticar, na presença de alguém menor de 14 (catorze) anos, ou induzi-lo a presenciar, conjunção carnal ou outro ato libidinoso, a fim de satisfazer lascívia própria ou de outrem; (Brasil, 1940)

${ }^{15}$ Art. 218-B. Submeter, induzir ou atrair à prostituição ou outra forma de exploração sexual alguém menor de 18 (dezoito) anos ou que, por enfermidade ou deficiência mental, não tem o necessário discernimento para a prática do ato, facilitá-la, impedir ou dificultar que a abandone. (Brasil, 1940)

${ }^{16}$ São os atos físicos que incluem toques nos órgãos genitais, tentativas de relações sexuais, masturbação, sexo oral e/ou penetração.
} 
demais formas de contato físico, mas também mediante outras modalidades que da mesma forma produzem abalos psicológicos gravíssimos, como a expressão verbal, falas erotizadas, o exibicionismo e a exposição a materiais pornográficos, sendo, portanto, diversas as variedades de cometimento de crimes sexuais.

Segundo dados do Ministério da Saúde (Brasil, 2018), entre o período de 2011 a 2017, houve um aumento de 83\% (oitenta e três por cento) nas notificações de violência contra crianças e adolescentes, sendo que a maioria das ocorrências aconteceram dentro do ambiente de convívio familiar das vítimas. Já em 2018, foram registrados no Brasil ao menos 32 (trinta e dois) mil casos de violência sexual contra crianças e adolescentes, havendo um índice superior a 35\% quanto a reiteração dos abusos (Brasil, 2018).

Já em 2019, foram divulgados pelo Ministério da Mulher, da Família e dos Direitos Humanos (MMFDH) que dos 159 mil registros feitos pelo Disque Direitos Humanos no decorrer do referido ano, 86,8 mil são de violações de direitos de crianças ou adolescentes, um aumento de quase $14 \%$ em relação a 2018. Salienta-se que em $73 \%$ dos referidos casos, o abuso ocorre na residência da vítima ou suspeito, sendo que em $40 \%$ destas denúncias os agressores são o próprio pai ou padrasto (Mmfdh, 2020).

Apesar da existência da legislação e dos órgãos protetores, parte das vítimas de abusos sexuais apresentam resistência em denunciar os agressores. Assim, o diagnóstico do abuso costuma ocorrer de duas formas, sendo a primeira quando realizado pelos pais ou familiares mediante a percepção de mudanças comportamentais da vítima, e a segunda quando a própria vítima passa a relatar os abusos, ao se sentir segura em virtude de um lapso temporal. (Campos, 2010).

Neste sentido, a dificuldade de incriminar o agressor está atrelada com o tempo que a vítima leva para fazer a denúncia, haja vista a dificuldade existente na coleta de matérias ou levantamento de indícios da agressão. Segundo alteração realizada no Código Penal brasileiro, através da Lei 12.650/2012 que alterou o prazo da prescrição dos crimes realizados contra menores, o prazo começa a contar a partir dos 18 anos completos da vítima e se estende por mais 20 anos para a realização da denúncia. Nesse sentido, Camões (2005, p. 2-3):

Quando eventualmente e criança decide transmitir a alguém os abusos sexuais, muitas vezes já se passaram meses ou até mesmo ano, o que comprometerá a perícia médica legal. A criança é de seguida encaminhada para um médico legista que irá fazer o exame médico-legal e envia-lo posteriormente para seguir os trâmites legais. Neste percurso muitas vezes o menor continua a conviver com o agressor, originando a perda de indícios e provas, que poderão prejudicar a incriminação do agressor. Durante o processo poderão também ocorrer informações contraditórias, ou indícios pouco significativos, que poderão afetar o normal desenrolar do processo judicial. Por todas estas razões encontramos menores que vêem por água abaixo a sua tentativa de "gritar por ajuda", e que muitas vezes desistem de pedi-la por acharem de que nada vale gritar quando esse grito não é ouvido pelos outros. Os pediatras são obrigados por lei a denunciar aos organismos responsáveis pela proteção adequada do menor, o diagnóstico ou suspeita de possível abuso ou negligência contra a criança. Os pediatras devem informar as famílias diretamente sobre a denúncia que será feita, de maneira delicada e compreensiva.

Percebe-se que as crianças e os adolescentes passaram a possuir especial proteção na legislação brasileira, sendo contempladas por uma série de direitos e garantias, das quais a família, a sociedade e o Estado possuem a responsabilidade de proteção. No campo de seu desenvolvimento, deverão ser protegidas de quaisquer violências, de negligência, discriminação, exploração, crueldade e opressão e, consequentemente, "resguardando seus direitos à vida, à saúde, à dignidade, ao respeito, entre outros" (Borges; \& Souza, 2018, p. 2-3), conforme prevê a Constituição Federal e o próprio Estatuto da Criança e do Adolescente.

A partir das bases constitucionais, principalmente o art. 227 da Constituição Federal de 1988 (Brasil, 1988) ${ }^{17}$, e com a

${ }^{17}$ Art. 227 É dever da família, da sociedade e do Estado assegurar à criança, ao adolescente e ao jovem, com absoluta prioridade, o direito à vida, à saúde, à alimentação, à educação, ao lazer, à profissionalização, à cultura, à dignidade, ao respeito, à liberdade e à convivência familiar e comunitária, além de colocá-los a salvo de toda forma de negligência, discriminação, exploração, violência, crueldade e opressão. 
promulgação do Estatuto da Criança e do Adolescente (ECA), foi estabelecido um sistema de garantias às crianças e aos adolescentes, além de ter se delineado o conceito de proteção integral à infância (Tavares, 2002, p. 9) ${ }^{18}$.

O abuso sexual é uma das formas mais graves de violência, atingindo um dos princípios fundamentais da Constituição Federal de 1988, o da dignidade da pessoa humana, violando os direitos humanos das crianças e adolescentes, pois, como sujeitos de direito, lhe são_garantidos a proteção integral e ao desenvolvimento sem violência (ECA, 1990).

Neste cenário, compete à família, à comunidade, à sociedade em geral e ao poder público assegurar a efetivação desses direitos. No caso do abuso sexual, portanto, deve haver a intervenção destes atores interdisciplinares (agentes judiciais, psicólogos, assistentes sociais, etc) para atender de forma humanizada a vítima e também punir o agressor (Pelisoli; Dobke; \& Dell'aglio, 2014).

A violência sexual cometida contra crianças e adolescentes tendem a causar danos físicos e também psicológicos, afetando diretamente a saúde das vítimas. Entre as consequências da violência, podem ser citados as lesões nos órgãos genitais, as doenças sexualmente transmissíveis, ou até mesmo a gravidez. Já quanto aos danos psicológicos, pode-se citar danos no desenvolvimento psicossocial, que podem repercutir ao longo da vida da vítima (Silva et al., 2013).

Diante da complexidade da violência e do abuso sexual, bem como considerando a dificuldade na preservação da prova material, haja vista o lapso temporal entre a ocorrência do abuso e o exame pericial, surge a necessidade de que a criança e o adolescente sejam ouvidos de forma especializada, tendo em vista seu estado de sujeito em formação, o que exige métodos adequados para sua escuta. Diante disso, o Conselho Nacional de Justiça (CNJ) estabeleceu orientações para tomada de depoimento de crianças e adolescentes (Santos; \& Coimbra, 2017).

[...] as propostas e práticas para a tomada de depoimento de crianças e adolescentes giram em torno dos seguintes itens: que ocorra uma única vez; o mais cedo possível; em sala diferenciada e pelo intermédio de profissionais capacitados - principalmente psicólogos ou assistentes sociais - a fim de que sejam feitas perguntas de forma mais adequada ao depoente. Nesse sentido, o projeto pioneiro que reuniu os itens citados ocorreu em 2003, no Tribunal de Justiça do Estado do Rio Grande do Sul. Essa prática foi denominada "Depoimento sem Dano", tendo por objetivo evitar a vitimização secundária de crianças e adolescentes envolvidos em crimes de natureza sexual (Santos; \& Coimbra, 2017, p. 596).

No ano de 2018, passou a vigorar a Lei $\mathrm{n}^{\circ}$. 13.431/17, que traz uma abordagem mais específica acerca das formas de violência contra as crianças e adolescentes, além de diretrizes sobre o sistema de garantias e direitos. A inovação dessa lei diz respeito, principalmente, a tomada de depoimento especial e escuta especializada, para que sejam evitadas a revitimização de crianças e jovens, vítimas da violência, ou seja, para que não precisem falar daquela violência por várias vezes, para diferentes profissionais.

Assim, diante da importância de se criar meios para garantir um atendimento prudente nos casos envolvendo violência sofrida ou presenciada, é que os mecanismos da Escuta Especializada e do Depoimento Especial se tornaram de suma importância na atualidade. Dessa forma, a próxima seção será dedicada ao estudo desses mecanismos, a fim de compreender o que é, e como são realizados, bem como quais os profissionais envolvidos em toda essa rede de proteção às vítimas ou testemunhas da violência sexual.

3.3 Escuta Especializada e Depoimento Especial: Uma análise dos procedimentos de oitiva de crianças e adolescentes vítimas ou testemunhas de violência

A sociedade brasileira, assim como o Estado, tem um importante papel na construção de alternativas que efetivamente garantam a proteção de crianças e adolescentes. Nesta seara, o Estado, ao tratar de jovens vítimas de violência e abusos

18 A proteção integral da criança e do adolescente expressa nesta lei, regula o art. 227 da CF/88, fazendo da família, do Estado e de toda a sociedade, os responsáveis por garantir a proteção dos titulares da lei. 
sexuais, procura evitar no curso judicial uma reevitimização, ou seja, expor a criança ou adolescente a repetidas situações de escuta. Assim, considerando a necessidade de atuação de diferentes áreas e a complexidade do problema, a escuta especializada e o depoimento especial são métodos importantes para reduzir a quantidade de pessoas e reiteradas oitivas da vítima, visando a efetividade da atenção prioritária e da proteção integral desses sujeitos (Santos et al., 2014).

O depoimento especial, conhecido inicialmente como depoimento sem dano (Homem, 2015) ${ }^{19}$, traz uma abordagem acerca da necessidade de a Justiça dialogar com outros saberes para um melhor direcionamento da realização deste ato processual, a oitiva da criança.

Com o advento da Lei $n^{\circ} .13 .431 / 17$, houve a determinação de que crianças e adolescentes sejam sempre ouvidos por meio dos procedimentos de escuta especializada e depoimento especial. O Depoimento Especial (DE) é uma prática de escuta de crianças e adolescentes vítimas de abuso sexual que objetiva minimizar os danos causados por recorrentes testemunhos. Isso significa que, quando houver uma violência, haverá uma cadeia de procedimentos a serem realizados por inúmeros órgãos, que buscam desde a proteção da vítima (encaminhamento médico e assistencial) até a busca pela punição do autor da violência (realização de perícia). Ocorre que, muitas vezes, as vítimas acabam tendo novos sofrimentos, como por exemplo, o fato de relatarem o evento traumático individualmente para cada um desses profissionais, relembrando a violência inúmeras vezes (Pini, 2018).

Conforme relatado na seção anterior pela Ouvidoria Nacional do Ministério da Mulher, da Família e dos Direitos Humanos (MMFDH), revelam que quase $90 \%$ dos casos de violência sexual contra crianças e adolescentes são registrados no ambiente familiar, sendo que 70\% das vítimas são mulheres (Camporez, 2019).

Quando a notícia do abuso chega a conhecimento de uma pessoa ela deve ser imediatamente levada a conhecimento da rede de proteção e o primeiro caminho muitas vezes será o Conselho Tutelar, que levará a conhecimento da autoridade policial para apuração do suposto crime. Nesse momento que os dois mecanismos previsto na Lei ${ }^{\circ}{ }^{13.431 / 17}$ serão postos em prática, qual seja a escuta especializada e o depoimento especial.

Conforme disposto no art. $7^{020}$, a escuta especializada trata-se de um sistema de entrevista, sobre as circunstâncias da violência sofrida pela criança ou adolescente, junto ao órgão da rede de proteção, ficando o relato da criança, limitado ao necessário para cumprir sua finalidade.

Segundo o Instituto Brasileiro de Direito de Família (IBDFAM) (2018, [online]), a escuta especializada visa proteger

\begin{abstract}
${ }^{19}$ A técnica do Depoimento Sem Dano nasceu em 2003, no Estado do Rio Grande do Sul, na Comarca de Porto Alegre por iniciativa do, à época, Juiz de Direito da $2^{\text {a }}$ Vara da Infância e Juventude, Doutor José Antônio Daltoé Cezar. A ideia do método teve origem em razão das inúmeras e variáveis dificuldades com que se deparava por ocasião das inquirições de crianças e adolescentes, sendo motivado a buscar alternativas distintas para o deslinde da colheita dos depoimentos. A priori, a técnica do Depoimento Sem Dano se referia apenas a uma experiência individual do magistrado, ainda sem amparo pelos tribunais. A primeira audiência por realizada pelo magistrado gerou um custo inicial de aproximadamente quatro mil reais, cujo valor foi suportado em iguais partes entre os envolvidos no processo, sendo eles autor, Promotor de Justiça, e ainda, recursos oriundos da Vara da Direção do Fórum. Com o investimento realizado, a Comarca passou a contar com um ambiente adequado para a realização da audiência do Depoimento Sem Dano, ambiente este devidamente equipado com câmera de segurança, computador, microfones, placa de captura de imagem e som, bem como suas respectivas instalações. Desta forma, apenas a Comarca de Porto Alegre no Rio Grande do Sul era detentora do ambiente propicio para a realização de tal audiência, sendo que em vista do sucesso dos atos realizados pelo juízo da Vara da Infância e Juventude, houve a disponibilização do ambiente nos períodos matutinos para que os demais Magistrados da Comarca de Porto Alegre, bem assim, a Comarcas do interior para que fizessem uso para a realização da audiência. Diante de todas as benesses, originadas por meio da utilização da técnica do Depoimento Sem Dano na desenvoltura dos depoimentos dos infantes e para a instrução processual, a técnica foi recepcionada pelo Tribunal de Justiça do Estado do Rio Grande do Sul e, no ano de 2004, aderiu caráter institucional, ocasião em que o citado Tribunal disponibilizou verbas para aquisição de equipamentos adequados, proporcionando assim uma melhoria na estrutura para utilização da técnica. Com o êxito das audiências realizadas no Estado do Rio Grande Sul, a utilização do método foi se expandindo para os outros Tribunais, como por exemplo, o Tribunal de Justiça de São Paulo, até que no ano de 2010 o Conselho Nacional de Justiça encampou a utilização do método o dando uma nova nomenclatura, passando a chamá-lo de "Depoimento Especial", onde por meio da Resolução 33/2010 (CONSELHO NACIONAL DE JUSTIÇA, 2010) recomendou aos Tribunais a criação de ambientes especiais para atendimento de crianças e adolescentes vítimas ou testemunhas de violência - um local reservado - e com o apoio de profissionais especializados que transmitem segurança para os depoimentos.

${ }^{20}$ Art. $7^{\circ}$ Escuta especializada é o procedimento de entrevista sobre situação de violência com criança ou adolescente perante órgão da rede de proteção, limitado o relato estritamente ao necessário para o cumprimento de sua finalidade.
\end{abstract}


a criança e ao adolescente e "não colheita de provas para eventual procedimento criminal, razão pela qual as perguntas devem se limitar ao necessário para garantir proteção e cuidados a infante".

Os artigos $8^{\circ}$ e $9^{\circ 21}$ da Lei $n^{\circ} 13.431 / 17$, definem que o depoimento especial é um procedimento de oitiva da criança, que tenha sido vítima ou testemunha de violência, devendo ocorrer perante autoridade policial ou judiciária, devendo a criança ou adolescente ser privado de qualquer contato com o provável autor do fato ou terceiro que represente risco a vítima e/ou testemunha, este possui a finalidade de produzir provas para o processo (Ibdfam, 2018). Assim, a escuta especializada e o depoimento especial, a partir da entrada em vigor da Lei $n^{\circ} 13.431 / 17$, tornaram-se as duas formas juridicamente admissíveis para que crianças ou adolescentes vítimas ou testemunhas de violência sejam ouvidas.

Todavia, cabe destacar que as referidas técnicas sofreram e sofrem críticas tanto por parte de alguns profissionais de determinadas categorias quanto da própria doutrina. Nessa linha, Digiácomo e Digiácomo (2018, p. 35) destacam:

\begin{abstract}
Mesmo antes da entrada em vigor da Lei, as disposições respectivas já foram objeto de controvérsia, seja em razão da resistência de algumas categorias profissionais em realizar a escuta, sobretudo das vítimas de violência, sob o argumento de que a diligência em si, ainda que tomadas todas as cautelas previstas, lhes causaria sofrimento, seja em razão de uma interpretação ainda mais restritiva acerca das possibilidades de coleta de prova junto a crianças e adolescentes vítimas ou testemunhas (que, se levada às últimas consequências, resultaria num retrocesso evidentemente indesejado pela norma).
\end{abstract}

O depoimento especial também foi aplicado na antecipação de prova, que visou a coleta do depoimento pela vítima de violência sexual, preservando a integridade da prova e a memória da parte ofendida. A respeito da aplicação da referida Lei, o Tribunal de Justiça do Rio Grande do Sul (TJRS), em sede de apelação criminal, na Sexta Câmara Criminal se manifestou da seguinte forma:

\begin{abstract}
APELAÇÃO CRIMINAL. AÇÃO CAUTELAR DE PRODUÇÃO ANTECIPADA DE PROVA. RECURSO MINISTERIAL QUE VISA À COLETA CAUTELAR ANTECIPADA DO DEPOIMENTO DE CRIANÇA TIDA COMO VÍTIMA DE VIOLÊNCIA SEXUAL, POR INTERMÉDIO DO "PROJETO DEPOIMENTO SEM DANO". APLICAÇÃO DA LEI 13.431/2017. A Lei n ${ }^{\circ}$ 13.431/2017 - também denominada de "Lei da Escuta Protegida", legislação editada para o fim de normatizar e organizar o "sistema de garantia de direitos da criança e do adolescente vítima ou testemunha de violência", bem como para criar "mecanismos para prevenir e coibir a violência" e estabelecer "medidas de assistência e proteção à criança e ao adolescente em situação de violência" $\left(\operatorname{art.~} 1^{\circ}\right)$ - dispõe, em seu art. 11, que o depoimento especial, "procedimento de oitiva de criança ou adolescente vítima ou testemunha de violência perante autoridade policial ou judiciária", seguirá o rito cautelar de antecipação de prova $\left(\S 1^{\circ}\right)$ quando "a criança ou o adolescente tiver menos de 7 (sete) anos" (inciso I) e "em caso de violência sexual" (inciso II). Ou seja, no caso de notícia da prática de violência sexual contra criança ou adolescente, a oitiva da vítima deve ser realizada por meio de depoimento especial, procedimento que deve ser realizado uma única vez (art. $11, \S 2^{\circ}$ ), para, além de preservar a integridade da prova e a memória da parte ofendida, cujo decurso do tempo, não raras vezes, a faz desaparecer ou alterar, preservar a dignidade e intimidade da vítima, bem assim evitar maiores traumas e o fenômeno do processo de revitimização, que geralmente ocorre com as reiteradas declarações dos ofendidos em outras fases processuais, resguardando-se, assim, as garantias, os direitos e os interesses das crianças e dos adolescentes previstos no art. 227 da Constituição Federal e na Lei no 8.069/1990 (Estatuto da Criança e do Adolescente). Os elementos constantes nos autos demonstram que a espécie se amolda à hipótese prevista na Lei de Escuta Protegida, porquanto há notícia de que vítima, que é adolescente e ainda não foi ouvida em sede inquisitorial, supostamente foi abusada sexualmente por seu tio quando tinha 13 (treze) anos de idade. APELO PROVIDO. (Apelação Criminal, $\mathrm{N}^{\circ}$ 70082593799, Sexta Câmara Criminal, Tribunal de Justiça do RS, Relator: Vanderlei Teresina TremeiaKubiak, Julgado em: 24-09-2019).
\end{abstract}

A técnica do depoimento especial também foi aplicada na ação de alteração de guarda sendo manifestada pelo órgão julgador, Oitava Câmara Cível, do TJRS, como sendo a mais adequada, tendo em vista que atende as particularidades da

\footnotetext{
${ }^{21}$ Art. $8^{\circ}$ Depoimento especial é o procedimento de oitiva de criança ou adolescente vítima ou testemunha de violência perante autoridade policial ou judiciária.

Art. $9^{\circ}$ A criança ou o adolescente será resguardado de qualquer contato, ainda que visual, com o suposto autor ou acusado, ou com outra pessoa que represente ameaça, coação ou constrangimento.
} 
situação em análise, como se verifica a seguir:

\section{AGRAVO DE INSTRUMENTO. AÇÃO DE ALTERAÇÃO DE GUARDA. PLEITO DE OITIVA DA INFANTE ATRAVÉS DA TÉCNICA DO DEPOIMENTO, ESPECIAL. CABIMENTO. DECISÃO REFORMADA.}

A Lei n. 13.341/2017 estabeleceu sistema de garantia de direitos da criança e do adolescente vítima ou testemunha de violência e, aqui, está englobada a violência psicológica, alegada pelo agravante. Reza em seu art. $5^{\circ}$, inciso VI, que, dentre outros direitos e garantias fundamentais, a criança e o adolescente deve "ser ouvido e expressar seus desejos e opiniões, assim como permanecer em silêncio". A escuta da criança em processos que lhe dizem respeito, mais do que um direito que o ordenamento jurídico lhe assegura, trata de uma atitude que procura valorizá-la como pessoa, evidenciando a importância que lhe está sendo dirigida, além de ser uma possibilidade de reconstrução de sua autoestima e expressão de sua emoção. Não basta, aliás, escutar a criança ou adolescente, devendo sua fala ser seriamente valorizada para fins de decisões judiciais, especialmente quando já possui condições de externar suas compreensões e desejos de maneira coerente e satisfatória, hipótese dos autos. Técnica do Depoimento Especial que se mostra adequada às particularidades da situação telada, justamente por respeitar a condição de pessoa em desenvolvimento e humanizar oitiva, através da qualificação dos profissionais que o realizam.Recurso provido. (Agravo de Instrumento. No 70081065864, Oitava Câmara Cível, Tribunal de Justiça do RS, Relator: José Antônio Daltoé Cezar, Julgado em: 12-06-2019). (Grifo nosso).

Assim, nas decisões colacionadas acima, principalmente na manifestação da Sexta Câmara Criminal, constata-se que o entendimento foi no sentido de resguardar a vítima, a fim de evitar a revitimização, haja vista que a notícia foi de que a adolescente supostamente foi vítima de violência sexual por parte do tio. Entretanto, a respeito do uso da técnica Lopes Junior e Rosa (2015, [online]) explanam que:

Acredita-se que a criança-adolescente vítima da agressão poderia expressar-se por palavras o que se passou em ambiente de perguntas e respostas, ainda que produzido em local diverso (sala do Depoimento Especial) e por profissionais, desconsiderando-se a especificidade de sua condição. A superação da oitiva pode se dar, como amplamente demonstrado pelos escritos de psicologia e serviço social por perícias e laudos que podem, mediante profissionais mais qualificados, obter informações de melhor qualidade (v.g. entrevista cognitiva). Os laudos são produzidos com respeito à vítima, no seu tempo, conforme as possibilidades e jamais em depoimentos gravados expressamente com essa finalidade. Ouvir vítimas não se confunde com inquirir. Duvidamos que se as ouça, porque, no fundo, servem apenas de meio de prova.

Percebe-se na crítica de Lopes Junior e Rosa que a apuração de provas de abusos sexuais poderia ser realizado de maneira diversa ao instituto do depoimento especial, preservando a vítima de uma inquirição psicologicamente dolorida. Neste sentido aponta alternativas como a realização de laudos por profissionais qualificados, com mesmo peso probatório de um depoimento gravado em juízo. Ainda sobre o depoimento especial, Perius e Barbosa (2019, p. 184-185) discorre sobre a contaminação da prova testemunhal, com as chamadas falsas memórias:

Os delitos cometidos em face de vítimas menores, principalmente no que tange aos delitos contra a dignidade sexual, elevam a prova testemunhal infantil à um patamar de credibilidade especial, em que suas declarações se revestem de caráter quase absoluto. Sendo assim, diante da utilização da prova testemunhal como alicerce probatório nesta espécie de infração, principalmente no que tange aos delitos cometidos em face de vítimas menores, faz-se oportuna a análise do principal elemento utilizado na reconstrução dos acontecimentos que serão narrados, a saber, a memória. Esta se configura como o principal ponto de controvérsia em matéria em credibilidade, haja vista a possibilidade de contaminação desse poderoso atributo humano. [...] a memória se manifesta de diversas formas e atua de maneiras distintas. Tendo em vista a existência constante de estímulos do cotidiano de toda a população, o armazenamento de dados na memória se torna algo constante, sendo as falsas memórias, portanto, fenômeno comum, apresentando-se nas mais diversas formas e podendo acarretar desvios de relatos em juízo. Tais desvios dependem de vários fatores de contaminação e, tendo em vista a maleabilidade da mente de crianças, estas mais facilmente conseguem criar falsas memórias. Uma falsa memória cotidiana pode passar desapercebida, sem qualquer influência negativa na realidade pessoal ou de terceiros. Entretanto, quando a falsa memória enseja condenações, ela acarreta injustiças, devendo ao máximo ser evitada. É interessante, neste ponto, evocar o caso da escola Base, principal exemplo brasileiro de como as falsas memórias prejudicam a vida, não só de quem imagina sofrer violência, como também do terceiro acusado.

Assim, a forma como a criança é inquirida, aliada ao trauma psicológico e a pressão exercida pelos pais faz com que 
estas, com anseio de contribuir na elucidação do crime, acabem por criar de maneira precipitada recordações falsas, acarretando em injustiças na condenação. Sobre isto, Lopes Júnior (2016, p. 398) explica que:

Impressiona a forma como foram conduzidos os depoimentos e a verdadeira indução ali operada. As perguntas eram fechadas e induziam as respostas, quase sempre dadas pela criança (recordemos, com 4 anos de idade) através de monossílabos (sim e não) ou, ainda, respostas que consistiam na mera repetição da própria pergunta. Naquele contexto, onde a indução era constante, e a pressão imensa, é elementar que as duas crianças sob holofote fantasiavam e também buscavam corresponder às expectativas criadas pelos adultos e pelo contexto. $\mathrm{O}$ caldo midiático criado e a desastrosa condução da investigação policial foram fundamentais para a inflação da imaginação das crianças e até das duas mães (sendo que uma delas era a principal fonte de tudo). A forma como foi conduzida a investigação policial (especialmente na oitiva das crianças envolvidas) serviu como um conjunto de exercícios imagéticos para alimentar as supostas vítimas. As consequências foram trágicas.

Sendo assim, tem-se demonstrado a constituição de falsas memórias, e a facilidade com que estas surgem, devendo este fator ser considerado nos depoimentos de vítimas e testemunhas de crimes, em especial nos casos que envolvem menores de idade, evitando-se assim condenações injustas.

Conforme o art. $8^{\circ}$ da Lei $n^{\circ} 13.431 / 17$, o "Depoimento especial é o procedimento de oitiva de criança ou adolescente vítima ou testemunha de violência perante autoridade policial ou judiciária”. Por outro lado, a escuta especializada, conforme o art. $7^{\circ}$ da mesma lei, consiste no "[...] procedimento de entrevista sobre situação de violência com criança ou adolescente perante órgão da rede de proteção, limitado o relato estritamente ao necessário para o cumprimento de sua finalidade". Ou seja, a principal diferença é o órgão que irá recolher o depoimento e todos devem respeitar o melhor interesse da criança. Para Silva (2018, p. 42-43):

A escuta especializada é feita por órgão da rede de proteção, que pode ser da educação, da saúde, da assistência social, da segurança pública e dos direitos humanos, tendo como finalidade acompanhar a vítima em suas demandas. Já o depoimento especial é realizado pelos órgãos investigativos de segurança pública e pelo sistema de Justiça, visando à apuração da autoria de supostos fatos criminosos no âmbito de um processo investigatório e, consequentemente, da responsabilização judicial do(s) acusado(s).

A Lei $\mathrm{n}^{\circ}$ 13.431/17 determina que no procedimento da escuta especializada e depoimento pessoal, a vítima da violência esteja em um local adequado e acolhedor, garantindo sua privacidade e a preservando de qualquer tipo de contato com o autor do fato ou outra pessoa que possa representar alguma ameaça. No depoimento especial, a vítima deve ser tratada por profissionais capacitados, que respeitem suas particularidades de sujeito em formação (Silva, 2018). Na mesma linha, o autor complementa:

Diante de todas as considerações acima expostas, há de se mencionar, por fim, que a presente lei é um marco decisivo para o depoimento especial enquanto método de inquirição de crianças e adolescentes vítimas de abuso sexual, ao prever não só os procedimentos a serem adotados para a oitiva e para a tomada do depoimento, mas também ao alinhar políticas públicas que englobam vários agentes e órgãos para prevenir a ocorrência de abusos e minimizar suas consequências (Silva, 2018, p. 43-44).

Caso esses procedimentos não sejam devidamente observados, a criança e o adolescente podem ser, novamente, vitimizados, em decorrência dos órgãos de atendimento e de justiça. Essa violência, originária dos procedimentos dos órgãos de atendimento, é chamada de violência institucional, um tipo de violência psicológica, que pode prejudicar o desenvolvimento psíquico e emocional. A violência institucional é aquela praticada pelos agentes estatais, por ação ou omissão, nas instituições públicas ou privadas prestadoras de serviços, que contrariem um atendimento humanizado, preventivo e reparador de danos (Chai, Santos, \& Chaves, 2018).

Com a lei, os órgãos de saúde, assistência social, educação, segurança pública e justiça "deverão adotar os 
procedimentos necessários para que o relato seja confirmado por meio da escuta especializada e/ou depoimento especial" (Pini, 2018, p. 2), exigindo capacitação profissional necessária dos envolvidos. A intenção é evitar que crianças e adolescentes sejam submetidos a reiteradas entrevistas, buscando a proteção dessas crianças (Pini, 2018).

Dessa forma, a escuta especializada e depoimento especial devem limitar-se ao estritamente necessário para o cumprimento de sua finalidade, cabendo aos órgãos e profissionais a reflexão sobre sua finalidade institucional e sobre quais são as informações necessárias para atingir essas finalidades. Conforme Silva (2018, p. 60):

[...] o método de inquirição de crianças e adolescentes denominado depoimento especial cumpre satisfatoriamente a função para a qual foi criado. Pode ser utilizado como único meio de prova em casos em que não seja possível a constatação (ou não) do suposto abuso de outras maneiras sem ferir diretamente princípios constitucionais e processuais. Porém, mostra-se fundamental ressaltar que o processo penal é dinâmico e que cada caso deve ser tratado de acordo com suas especificidades e peculiaridades. Nesse sentido, deve-se sempre buscar novas alternativas para que a técnica se modernize e se aperfeiçoe [...].

Diante disso, observa-se que esses procedimentos visam proporcionar à vítima ambientes especiais, com atendimento integrado e interdisciplinar, preocupados com o bem-estar da criança e do adolescente, buscando evitar a revitimização da criança e adolescente, sendo um dos pontos centrais do método a inquirição única, justamente para evitar a exposição da vítima a novos traumas.

\section{Considerações Finais}

O presente artigo buscou verificar como a defesa dos direitos das crianças e adolescentes tem avançado nos últimos anos, sendo seu principal foco na análise da Lei $\mathrm{n}^{\circ}$ 13.431/2017, e de que forma a referida lei vem contribuindo para assegurar e promover o direito das crianças de serem ouvidos em processo judicial.

No curso da pesquisa constatou-se que o ordenamento jurídico brasileiro dispõe de normas de proteção integral à toda e qualquer criança e adolescente, possuindo avanços na construção de políticas públicas e da defesa de direitos dessa população, para que tenham desenvolvimento físico, mental, moral, espiritual e social em condições de liberdade e de dignidade.

Na contramão desse cenário de garantias e proteção, tem-se a violência perpetrada contra as crianças e os adolescentes que se mostra como um fenômeno social e cultural extremamente preocupante, carecendo de todos os meios possíveis para auxiliar as estes jovens a irem em busca da justiça. Assim, a busca pela defesa dos direitos da criança e do adolescente, com a principal finalidade de coibir a violência sofrida por estes, ganhou em 2017 uma nova legislação, a Lei nº 13.431/2017, o qual constitui-se em um dos mais recentes mecanismos destinados a coibir a violência contra esses jovens, as inovações legislativas introduzidas pela referida lei, se somam às normas já existentes, implementando formas mais eficazes na tentativa proteger as vítimas e testemunhas de violência sexual.

Dessa forma, a Lei $n^{\circ}$ 13.431/2017 é uma forma relevante de oitiva de testemunhas, considerando que proporciona condições adequadas para que as crianças e adolescentes vítimas de abuso possam ser ouvidas, demonstrando que o Estado Brasileiro vem se empenhando em garantir um sistema legal que seja voltado a proteção integral e o melhor interesse para crianças e adolescentes.

A implantação do instituto do Depoimento especial de forma efetiva nas diversas comarcas do país, constitui-se como um forte incentivo para afastar a criança de um ambiente cheio de formalismos, frente a audiências tradicionais, que não se mostram mais condizentes com a inquirição destas vítimas ou testemunhas, ocasionando danos emocionais ou psíquicos ao reviver os fatos, ou seja, resultando em uma revitimização.

Entre os pontos positivos do depoimento especial, pode-se destacar a forma que a entrevista é rigorosamente 
registrada, a documentação visual dos gestos e expressões faciais que acompanham os enunciados verbais das crianças, que pode ser visto muito tempo depois por outros profissionais, a redução de entrevista por parte de outros profissionais, a forma de capacitação contínua para outros entrevistadores.

O bem estar da criança e do adolescente deve sempre vir em primeiro lugar, lhes assegurando o mínimo de dignidade, de modo que o depoimento especial, efetivado na Lei $n^{\circ}$ 13.431/17, garante às crianças e aos adolescentes direito de não ter contato direto com o seu agressor minorando os possíveis efeitos da violência já sofrida.

Não obstante, parte da doutrina não vem somente com bons olhos a oitiva da criança e do adolescente através do depoimento especial, visto que as crianças estão expostas à indução por meio do entrevistador, uma vez que podem ser facilmente manipuladas, podendo responder a perguntas tendenciosas que possam apontam a um abuso que na verdade nunca houve.

Entretanto, em que pese haver divergências doutrinárias a respeito do assunto, constata-se a relevância da Lei em estudo, pois é eficaz em proteger os jovens de uma revitimização, uma vez que delimita a escuta para apenas um ato, resguardando a vítima de sucessivas inquirições sobre o mesmo fato. Além do mais, a referida Lei assegura meios para atendimento e acompanhamento especializado por profissionais capacitados, resguardando os direitos das crianças e dos adolescentes no curso da escuta pelo Depoimento especial, sendo fundamental para o não agravamento do abalo psicológico já existente.

\section{Referências}

Barros, L. S. C. (2014). A Doutrina da proteção integral e sua gênese. Conteúdo Jurídico. https://conteudojuridico.com.br/consulta/Art.s/38735/a-doutrina-daprotecao-integral-e-sua-genese\#: :text=Em\%201899\%2C\%20os\%20Estados\%20Unidos,Juizado\%20de\%20Menores\%20do\%20pa\%C3\%ADs.

Borges, G.; \& Souza, I. F. (2018). A escuta qualificada e o depoimento especial: desafios da Lei no $13.431 / 17$ na busca da não revitimização de crianças e adolescentes. In: Seminário Internacional de Demandas Sociais e Políticas Públicas na Sociedade Contemporânea, 15, Santa Cruz do Sul. Anais [...]. Universidade de Caxias do Sul.

Brasil. (1940). Decreto Lei no 2.848, de 07 de dezembro de 1940. Código Penal. Presidência da República. http://www.planalto.gov.br/ccivil_03/decretolei/del2848compilado.htm.

Brasil. (1988). Constituição da República Federativa do Brasil de 1988. Presidência da República. http://www.planalto.gov.br/ccivil_03/constitui cao/constituicao.htm.

Brasil. (1990). Lei no 8.069, de 13 de julho de 1990. Estatuto da Criança e do Adolescente. Presidência da República. Dispõe sobre o Estatuto da Criança e do Adolescente e dá outras providências. http://www.planalto.gov.br/ccivil_03/leis/18069.htm.

Brasil. (2017). Lei ${ }^{\circ}$ 13.431, de 4 de abril de 2017. Estabelece o sistema de garantia de direitos da criança e do adolescente vítima ou testemunha de violência e altera a Lei $\mathrm{n}^{\mathrm{o}}$ 8.069, de 13 de julho de 1990 (Estatuto da Criança e do Adolescente). http://www.planalto.gov.br/ccivil_03/_Ato20152018/2017/Lei/L13431.htm.

Brasil, Ministério da Saúde. (2018). Análise epidemiológica da violência sexual contra crianças e adolescentes no Brasil, 2011 a 2017. Boletim Epidemiológico 2018; 49(27). https://portaldeboaspraticas.iff.fiocruz.br/wp-content/uploads/2019/07/2018-024.pdf

Brasil. Superior Tribunal de Justiça. (2020). Recurso Ordinário em Habeas Corpus no 117.204-SP (2019/0252782-3). Recorrente: A. Z da S (Preso). Recorrido: Ministério Público do Estado de São Paulo. Relator: Ministro Reynaldo Soares da Fonseca. Brasília, 28 de fevereiro de 2020. https://stj.jusbrasil.com.br/jurisprudencia/861792709/recurso-em-habeas-corpus-rhc-117204-sp-2019-0252782-3.

Camões, C. (2005). Violência Sexual em Menores. Psicologia: o portal dos psicólogos, [s. 1]. http://www.psicologia.pt/art.s/textos/A0245.pdf.

Camporez, P. (2019). Ministério dos Direitos Humanos conclui que quase $90 \%$ da violência sexual contra crianças acontece no ambiente familiar: Mais de $70 \%$ das vítimas são mulheres, de acordo com levantamento baseado em denúncias feito ao Disque 100. O Globo, Sociedade. https://oglobo.globo.com/sociedade/ministerio-dos-direitos-humanos-conclui-que-quase-90-daviolencia-sexual-contra-criancas-acontece-no-ambientefamiliar-23665391.

Campos, L. V. (2010). Abuso Sexual. Mundo Educação. https://mundoeducacao.bol.uol.com.br/sexualidade/abuso-sexual.htm.

Carreirão, E. C. O. (2002). O adolescente e o atendimento Publico de saúde: as mudanças com o advento do Estatuto da Criança e do Adolescente. 2002.129 f. Mestrado (Mestrado em Saúde Pública) - Universidade Federal de Santa Catarina.

Chai, C. G., Santos, J. P. d., \& Chaves, D. G. (2018). Violência institucional contra a mulher: o poder judiciário, de pretenso protetor a efetivo agressor. Revista Eletrônica do Curso de Direito, 13(2), 640-665. https://doi.org/10.5902/1981369429538 
Childhood Brasil. (2018). Tipos de abuso sexual de crianças e adolescentes: Abuso sexual pode acontecer com ou sem contato físico. https://www.childhood.org.br/tipos-de-abuso-sexual-de-criancas-eadolescentes.

Coelho, T. (2018). Maioria dos casos de violência sexual contra crianças e adolescentes ocorre em casa; notificações aumentaram 83\%: Dados do Ministério da Saúde entre 2011 e 2017 revelaram perfil das vítimas e dos agressores. Casos continuam subnotificados. G1, Ciência e Saúde. https://g1.globo.com/cienciae-saude/noticia/maioria-dos-casos-de-violencia-sexual-contracriancas-e-adolescentes-ocorre-em-casa-notificacao-aumentou-83.ghtml.

Dantas, S. E. (2009). Redução da idade penal em face da Constituição Federal: Apontamentos jurídicos acerca das tentativas de redução da idade para imputação criminal do menor de 18 anos. Revista Jus Navigandi, Teresina, 14(2373). https://jus.com.br/art.s/14105.

Delfino, M. (2009). O princípio do melhor interesse da criança e o direito à convivência familiar: os efeitos negativos da ruptura dos vínculos conjugais. Monografia (Bacharelado em Direito) - Pontifícia Universidade Católica do Rio Grande do Sul. http://www3.pucrs.br/pucrs/files/uni/poa/direito/graduacao/tcc/tcc2/trabalhos2009_1/morgana_delfino.pdf.

Digiácomo, M. J., \& Digiácomo, E. (2018). Comentários à Lei no 13.431/2017. Ministério Público do Paraná. http://www.crianca.mppr.mp.br/arquivos/File/publi/caopca/lei_13431_comentada_jun2018. pdf.

Durkheim, E. (1987). As regras do método sociológico. 13. Nacional (Texto originalmente publicado em 1895).

Facuri, C. O. et al. (2013). Violência sexual: um estudo descritivo sobre as vítimas e o atendimento em um serviço universitário de referência no Estado de São Paulo. Cad. Saúde Pública, 29(5), p. 889-898. https://assetscompromissoeatitudeipg.sfo2.digitaloceanspaces.com/2 013/11/CLAUDIAFACURIETAL_CAISM2013_art.viol enciasexual.pdf.

Fundo das Nações Unidas para a Infância - (UNICEF). (21--?)a. História dos direitos da criança: Os padrões internacionais avançaram radicalmente ao longo do século passado - conheça alguns marcos na história desses direitos no Brasil e no mundo. UNICEF. https://www.unicef.org/brazil/historia-dos-direitos-dacrianca.

Fundo das Nações Unidas para a Infância - (UNICEF). (21--?)b. O que é o UNICEF. UNICEF. https://www.unicef.org/brazil/perguntas-frequentes.

Gadotti, M. (2015). ECA - avanços e desafios. In: Vieira, A. L.; Pini, F.; \& Abreu, J. (org.). Salvar o Estatuto da Criança e Adolescente (ECA). Instituto Paulo Freire.

Gomes, L. F.; Donati, P.; \& Fernandes, D. (2009). Conjunção carnal sem violência com adolescente de catorze anos de idade: atipicidade. Rede de Ensino Luiz Flávio Gomes. http://www.lfg.com.br04junho.

Habigzang, L. F. et al. (2005). Abuso sexual infantil e dinâmica familiar: aspectos observados em processos jurídicos. Psicologia, Teoria e Pesquisa.

Homem, É. P. (2015). Depoimento sem dano e o melhor interesse da criança: O Depoimento Sem Dano sob a ótica do princípio do melhor interesse da criança e sua importância para o processo penal. MPPR. http://www.crianca.mppr.mp.br/pagina-2231.html.

Instituto Brasileiro de Direito de Familia - (IBDFAM). (2018). Decreto que estabelece procedimentos para escuta de crianças e adolescentes é promulgado. IBDFAM. http://www.ibdfam.org.br/noticias/6837/+Decreto+que+estabelece+procedimentos+para+ escuta+de+crian\%C3\%A7as+e+adolescentes+\%C3\% A9+promulgado.

Ishida, V. K. (2015). Estatuto da Criança e do Adolescente: Doutrina e Jurisprudência. 16. Atlas.

Jensen, S. C. (2018). Os Documentos Internacionais Sobre os Direitos das Crianças e dos Adolescentes. Jornal de Relações Internacionais. https://jornalri.com.br/art.s/os-documentos-internacionais-sobre-os-direitos-das-criancas-e-dos-adolescentes.

Jerez, D. M. et al. (2013). O direito à proteção integral das crianças e dos adolescentes no contexto de grandes empreendimentos: papéis e responsabilidades das empresas. 1(1), 5-6. Direito GV. https://bibliotecadigital.fgv.br/dspace/bitstream/handle/10438/18797/GDHeE_Jerez\%3B\%20 Almeida\%3B\%20Scabin\%3B\%20Neiva\%3B\%20Poppovic\%3B\%20Vieira\%3B\%20Brezighe llo.pdf?sequence=1\&isAllowed=y.

Lopes Junior, A. (2016). Direito Processual Penal. Saraiva.

Lopes, A.; \& Rosa, A. M. (2015). Depoimento Especial é antiético e pode levar a erros judiciais. Revista Consultor Jurídico. https://www.conjur.com.br/2015jan-23/limite-penal-depoimento-especial-antieticolevar-erros-judiciais.

Masella, M. A. (2014). A inclusão do adolescente autor de ato Infracional e a rede de proteção: um olhar interdisciplinar. 108 f. Tese (Doutorado em Educação) - Pontifícia Universidade Católica de São Paulo. http://www4.pucsp.br/gepi/downloads/TESES_CONCLUIDAS/2014-TESEMARCIO\%20MASELLA.pdf.

Mendes, M. P. (2006). A doutrina da proteção integral da criança e do adolescente frente à Lei 8.069/90 [Doctoral dissertation, Pontifícia Universidade Católica de São Paulo]. http://www.dominiopublico.gov.br/download/teste/arqs/cp009234.pdf

Minayo, M. C. S. (1983). Quantitativo-Qualitativo: oposição ou complementaridade. Cadernos de Saúde Pública. 9(3), 239-62.

Minayo, M. C. S. (2001). Violência contra crianças e adolescentes: questão social, questão de saúde. Revista Brasileira de Saúde Materno Infantil [online]. 1(2), pp. 91-102. https://doi.org/10.1590/S1519-38292001000200002.

Organização Mundial da Saúde (OMS). (2018). OMS aborda consequências da violência sexual para saúde das mulheres. https://brasil.un.org/pt-br/80616oms-aborda-consequencias-da-violencia-sexual-para-saude-das-mulheres

Paraná. (2020). Ministério Público do Estado do Paraná. Estatísticas: Três crianças ou adolescentes são abusadas sexualmente no Brasil a cada hora. MPRP. http://www.crianca.mppr.mp.br/2020/03/231/ESTATISTICAS-Tres-criancas-ou-adolescentessao-abusadas-sexualmente-no-Brasil-a-cada-hora.html. 
Pelisoli, C.; Dobke, V.; \& Dell'aglio, D. D. (2014). Depoimento Especial: Para Além do Embate e pela Proteção das Crianças e Adolescentes Vítimas de Violência Sexual. Temas em Psicologia, 22(1). http://pepsic.bvsalud.org/pdf/tp/v22n1/v22n1a03.pdf.

Perius, G. H. M. F. M.; \& Barbosa, I. A. (2019). A oitiva do menor de idade, conforme a lei 13.431/17 e a sua possível contribuição para a redução das falsas memórias em crimes que não deixam vestígios. Vertentes do Direito, 6(1). https://sistemas.uft.edu.br/periodicos/index.php/direito/article/view/6649/15303.

Pinheiro, L. A. (2014). O "magistrado paternal”: o Juiz Mello Mattos e a assistência e proteção à infância (1924-1933). 231 f. Tese (Doutorado em História das Ciências e da Saúde) - Fundação Oswaldo Cruz. https://www.arca.fiocruz.br/handle/icict/17808.

Pini, L. G. (2018). Depoimento de jovem vítima de crime exige atenção e cuidados especiais. Revista Consultor Jurídico. https://www.conjur.com.br/2018fev-18/livia-pini-sadsddssdsd.

Popper, K. S. (1975). A lógica da pesquisa científica. 2. Cultrix.

Rio Grande do Sul. (2019). Secretaria de Saúde. Centro Estadual de Vigilância em Saúde - CEVS. Tipologia da Violência. Secretaria de Saúde. https://www.cevs.rs.gov.br/tipologia-da-violencia.

Rio Grande do Sul. (2019). Tribunal de Justiça (6. Câmara Criminal). Apelação Criminal No 70082593799. Apelação criminal. Ação cautelar de produção antecipada de prova. Recurso ministerial que visa à coleta cautelar antecipada do depoimento de criança tida como vítima de violência sexual, por intermédio do "projeto depoimento sem dano". Aplicação da Lei 13.431/2017. A Lei no 13.431/2017. Relator: Vanderlei Teresina Tremeia Kubiak, Porto Alegre, 24 de setembro de 2019. http://www.tjrs.jus.br/site/buscasolr/index.html?aba=jurisprudencia.

Rio Grande do Sul. (2019). Tribunal de Justiça (8. Câmara). Agravo de Instrumento No 70081065864. Agravo de instrumento. Ação de alteração de guarda. Pleito de oitiva da infante através da técnica do depoimento especial. Cabimento. Decisão reformada. Agravante: F.C.C. Relator: José Antônio Daltoé Cezar, 12 de junho de 2019). https://www.tjrs.jus.br/buscas/jurisprudencia/exibe_html.php.

Santos, A. R.; \& Coimbra, J. C. (2017). O Depoimento Judicial de Crianças e Adolescentes entre Apoio e Inquirição. Psicologia: Ciência e Profissão, 37(3). https://doi.org/10.1590/1982-3703004032016.

Santos, B. R. et al. (2014). Escuta de Crianças e Adolescentes em situação de violência sexual. ChildHood. http://childhood.org.br/publicação.

Santos, C. G. (2015). O Estatuto da Criança e do Adolescente e o Ministério Público. In: Vieira, A. L.; Pini, F.; \& Abreu, J. (org.). Salvar o Estatuto da Criança e Adolescente (ECA). Instituto Paulo Freire.

Severino, A. J. (2018). Metodologia do trabalho científico. 24. Cortez.

Silva, B. S. S. (2018). A importância do depoimento especial como método eficaz de inquirição de crianças e adolescentes vítimas de abuso sexual. 67 f. Trabalho de Conclusão de Curso (Bacharelado em Ciências Jurídicas e Sociais) - Universidade Federal do Rio Grande do Sul. https://www.lume.ufrgs.br/bitstream/handle/10183/174673/001061531.pdf?sequence=1.

Silva, L. M. P.; et. al. (2013). A escuta de crianças e adolescentes nos processos de crimes sexuais. Ciência \& Saúde Coletiva, 18(8), p. 2285-2294. https://www.scielosp.org/pdf/csc/2013.v18n8/2285-2294/pt.

Silva, R. L. (2009). A proteção integral dos adolescentes internautas: limites e possibilidades em face dos riscos no ciberespaço. Tese (Doutorado em Direito) Universidade Federal de Santa Catarina. http://www.egov.ufsc.br/portal/sites/default/files/tese_a_protecao_integral.pdf.

Souza, S. A. G. P. (2002, January 1). A declaração dos direitos da criança e a convenção sobre os direitos da criança. Direitos humanos a proteger em um mundo em guerra. Revista Jus Navigandi, 7(53). https://jus.com.br/artigos/2568/a-declaracao-dos-direitos-da-crianca-e-a-convencao-sobre-os-direitos-dacrianca

Tavares, J. F. (2002). Comentários ao Estatuto da Criança e do Adolescente. Forense.

Venâncio, R. P.; \& Marcílio, M. L. (1999). História Social da Criança Abandonada. Revista Brasileira de História, 19(37).

Vieira, A. L.; Pini, F.; \& Abreu, J. (2015). Salvar o Estatuto da Criança e Adolescente (ECA). Instituto Paulo Freire.

Westin, R. (2015). Crianças iam para a cadeia no Brasil até a década de 1920. Agência Senado. https://www12.senado.leg.br/noticias/materi as/2015/07/07/criancas-iam-para-a-cadeia-no-brasil-ate-a-decada-de-1920.

Zapater, M. (2018). As duas infâncias do Código de Menores de 1979. Justificando, [s. 1.]. http://www.justificando.com/2018/02/16/as-duas-infancias-docodigo-de-menores-de-1979/.

Universidade de Cruz Alta. (2020). Manual de Normalização de Trabalhos Acadêmicos da Universidade de Cruz Alta - UNICRUZ. Unicruz - Centro Gráfico. 